\title{
Leading Pedagogical Possibilities in Children's Public Organizations and Personality Formation
}

\author{
Nadezhda Zhmakina \\ Faculty of Pedagogy and Psychology \\ Nizhnevartovsk State University \\ Lenin str. 56, 628605 Nizhnevartovsk \\ Russian Federation \\ e-mail: zm-nadya@mail.ru \\ Liliya Ibragimova \\ Faculty of Pedagogy and Psychology \\ Nizhnevartovsk State University \\ Lenin str. 56, 628605 Nizhnevartovsk \\ Russian Federation \\ e-mail: laibra@yandex.ru \\ Tatyna Dergunova \\ Faculty of Pedagogy and Psychology \\ Nizhnevartovsk State University \\ Lenin str. 56, 628605 Nizhnevartovsk \\ Russian Federation \\ e-mail: derg_t5@mail.ru
}

\begin{abstract}
This article reveals the content of concepts: "children's public organization", "children's public association". Based on the above analysis of various approaches to the content of the concept of "children's social organization", the main distinguishing features of this phenomenon are highlighted: amateur character, the presence of statutory documents, a composition that includes children and adults, united by a common goal, tasks and content. The analysis of the scientific works of researchers on the problem of the educational space as a pedagogically organized environment, which creates not only additional, but also new opportunities in the development of leadership qualities of adolescents, contributes to the inclusion of adolescents in a variety of activities where the adolescent gains experience of leadership behaviour. Based on the analysis of scientific works, several basic positions on the educational space are formulated: space is a developed environment adapted for solving educational problems; the concepts of "environment" and "space" are not identical; educational space is becoming a factor in the humanization of children's life. An important characteristic of the educational space is its activity, understood as the ability to maintain in a group a level of emotional and intellectual tension sufficient for all participants in the interaction, stimulate the child's interrogative attitude to the world and creatively search for answers to questions that arise during his life. The active educational space is different in that it provides each child with the opportunity to meet new people, objects and phenomena, and enables each child to show his personal potential. The article also emphasizes that children's public organizations can be considered as an educational space for the development of not only the leadership qualities of adolescents, but also feelings of tolerance, selfconfidence, the ability to express themselves, and develop skills to engage in intercultural dialogue.
\end{abstract}

\section{Introduction}

At various stages of the historical development of our country, unique experience has been gained in organizing a variety of children's structures, which are presented in documents, programs, studies, manuals and methodological literature, but due to the collapse of mass pioneer and Komsomol organizations, children in Russia found themselves in a social vacuum. Meanwhile, children's organizations are an integral part of society in all modern countries; they are a real kind of social movement. In addition to meeting the needs of children and adolescents in communication, joint activities on interests, these organizations also perform other social functions. They include adolescents in society, serve as a means of building social skills, protecting the interests and rights of children. Participation in children's organizations allows you to gain social experience, contributes to the formation of civic qualities necessary for life in a democratic society.

At present, Russia does not have: a single center that would coordinate and combine the efforts of children's public organizations to form socially significant tasks related to self-realization of a person; implementation of a 
structured state policy in the field of children's public organizations; imparting socially significant character to children's public organizations; increase in the number of children's public organizations. Therefore, modern "children's public organizations" are aimed at providing assistance, protecting the rights and interests of students, identifying leadership qualities, creating a microclimate for their self-realization.

Scout organizations, including in our country, enjoy great influence at the present time. Confessional organizations, pacifist organizations (including the International Children's Summer Villages, Samantha Smith Foundation, Children as Peacemakers, Children as Teachers of the World), environmental branches of the Green Party, etc., numerous student organizations, are also widespread. student and other educational organizations. School and student squads engaged in the search for the missing during the Great Patriotic War became very widespread in our country.

Children's movements and organizations in Russia today include hundreds of activities, thousands of annual events, a lot of amazing ideas and often really useful and meaningful initiatives. There are more than 800 such organizations in Moscow alone. These are scouts and peacekeepers, pioneers and patriots, environmentalists and tourists, artists and journalists, young historians and local historians ... Everyone is united by youth and a desire to make the world around you and your life brighter, more interesting, more saturated, which means it's better. The life of the children's movement is a real kaleidoscope of amazing events, interesting events and projects.

Modern children's associations are engaged in charity affairs, organize outdoor activities, compete in intellectual and sports tournaments, and initiate environmental projects. Without them, the upbringing of young leaders cannot take place in full, organizations like no other help the children to socialize, communicate and make friends.

Modern children's organizations are different in form, structure, degree of coordination, goals, content and directions of activity. Children's public organizations often involve a complex structure and documentation, the development of a charter, the creation of a system of governing bodies. But there are also informal organizations that arise on the basis of amateur interests or interest groups, entertainment preferences.

In place of party decisions that regulate and regulate the activities of organizations, today came state acts to support the children's movement in Russia. The rejection of tight public-state control contributed to the active development of informal amateur structures. Since the 1990s, various children's associations have been created and legally supported in Russia. In December 2006, the Government of the Russian Federation adopted a strategy for the youth policy of the Russian Federation. A lot of this document is written about the activities of children's organizations and their support.

At the same time, the lack of a unified methodological service, the loss of established systems for training, retraining and advanced training of personnel, the problems of financial support indicate serious problems in the development of the children's movement in modern Russia. At the federal level, there is no single executive body uniting representatives of all or most of the current organizations.

However, the positive development trends of some children's organizations and movements suggest that these associations can become a stable basis for the formation of the fundamental values of the younger generation and develop the unique human and personal qualities of children. Good traditions are not forgotten and the guys come together again for good and interesting things.

At present, Russia has a large number of children's public associations of various types and forms. By territorial coverage, one can distinguish all-Russian, inter-regional, regional and local associations. Children's organizations based on schools are widespread: student committees, unions, associations, "republics", etc. Also, modern children's associations can be divided into areas of their activities.

\section{Educational potential of children's public organizations}

Children's public organizations have enormous educational potential, since, on the one hand, they are an extremely important medium for self-realization, on the other hand, an important factor in socialization, and on the third, a real tool for protecting the rights and interests of children

For example, Maltseva (2005) notes that a children's public organization is defined as an amateur, selfgoverning association of children sharing the ideas of adults, equally participating in socially significant activities, having the norms and rules governing the activity, fixed in the Charter or other constituent document, a certain structure and fixed membership.

According to Bondar's definition (2013), a children's public organization is an amateur, self-governing voluntary association of children and ideas that share them, the beliefs of adults equally participating in socially significant activities, realizing individual and social needs and relationships, which has a pronounced structure that regulates activities, norms and rules enshrined in the charter or other constituent instrument and fixed membership.

In addition, Volokhov (2003) notes that a "children's public organization" is a voluntary independent, selfgoverning, on the basis of the charter (and other documents) equal association of children and adults, created for joint activities to realize and protect the interests of those unifying. 
A children's public organization is an amateur, self-governing children's public association created to implement any social idea (goal), having the norms and rules that regulate its activity, fixed in the charter or other constituent document, a pronounced structure and fixed membership.

The essential feature of a children's social organization is amateurish, thanks to the variety of social roles, students are involved in various managerial activities and the essential characteristic of a children's public organization is the relationship between adults and children, built on dialogue with adults who are members of these organizations. Adults, as partners in joint activities, help students in understanding the new social experience, in developing adequate ways to interact with the world, and orientation in the value system. Partnership is built on the basis of cooperation, co-creation, ownership and creation of socially valuable relations (Bondar 2013).

From the point of view of social psychology, the essence of a child's organization can be defined as characteristic of a given community — a social organism - as a value-motivational foundation that advances the satisfaction of the social claims of a child of a certain age in his real relationships with the material world, with the surrounding reality, representing the social interests of children in various public areas contributing to the full development of personal qualities and environmental capabilities.

From the point of view of sociology, the essence of a children's social organization is defined as a specific sociocultural education that integrates the life values of childhood, the real possibilities of ensuring the diverse needs and interests of the child in this society.

From a pedagogical point of view, the essence of a child's organization can be represented as an integrated set of specially created environmental conditions that ensure sustainable social and pedagogical culture-forming relationships between children and adults as equal partners with different social status, aimed at optimizing their social development and improving the surrounding living space (Dmitrenko 1996)

The main features of modern children's public organizations are:

- abandonment of a large number of children, therefore, the duration of most children's organizations is short and amounts to 2-3 years;

- changing the status of participants in children's public organizations from 6 to 18 years old; the entry of adults into the composition of children's public organizations.

Children's public organizations at the moment are not directly related to parties, however, they are ready for cooperation, operate within the framework of the Constitution of the Russian Federation on the conditions of support and protection of childhood (Bondar 2013). From the point of view of goals, objectives and content of activities, children's organizations are distinguished:

- $\quad$ those focused on the socialization of the personality of the child, his civic formation, harmonization of personal and social, individual and collective principles;

- related to the initial professional training of children (Business Clubs, Schools of Entrepreneurs, League of Young Journalists, etc.);

- $\quad$ socially individual orientation (mainly scout organizations); children's public structures that promote patriotic, civic education (youth clubs, police friends, etc.);

- cultural and practical in nature (to revive traditions, study the history and culture of the peoples of Russia, folk crafts);

- $\quad$ fighting for the adoption of a healthy lifestyle (sports, tourism).

Children's public organization includes schoolchildren in broad social relations, takes an intermediary position between childhood and society. The real possibility of a children's social organization, which determines its essence, is that a children's public organization unites qualitatively new advanced social values, initiatives, and experiences of the young generation. On the one hand, they are oriented toward satisfying the needs of an affirming personality, and on the other, at reorganizing the surrounding reality and improving social relations.

One of the public children's structures is also a children's public association. Despite the fact that there are different approaches to the definition of the concept of "children's public association", the points of view of the researchers are largely the same.

According to Kulpedinova (1996) children's public association is an independent social formation of children and adults created on a voluntary basis for joint activities in order to meet children social needs and interests. Moreover, Chugunova (2000) gives the following definition: "a children's association is a type of small group functioning as a social organization with a freely formed organizational structure, an adult-child democratic hierarchy, and active personal social relations carried out in roles whose content forms the interaction within the group".

Speaking of children's public association, the authors of the textbook "Pedagogy of the Children's Movement" Maltseva and Kostina (2000) examine the essence of a children's public association in three aspects. The social aspect is manifested in the need of society to institutionalize the social activity of children, to include 
them through the children's public association in the development of the experience of social relations, that is, to direct the socialization of the child in a socially approved direction. Through the children's public organization, the child is not only enriched with experience, but also realizes himself as a person, influencing life circumstances and surrounding people.

The psychological aspect is associated with the realization of children's desire for communication. Children's public association expands the child's self-image, contributes to the realization of ideal ideas about their role, life path. The pedagogical aspect is manifested in the fact that the children's public association takes an intermediary position between children and society, creates the conditions for harmonizing the experience of collective and individual relations.

According to a study by Chugunova (2000), inclusion in a children's public association allows a teenager to more fully satisfy their social needs, realize their aspirations and interests, for which there are not sufficient conditions in other types of children's associations.

The desire of adolescents to unite is a natural need for this age, because, uniting in groups, they seek to assert themselves, to fulfill themselves. The dominant feature of this age period is communication and action. It is in communication with a teenager that the norms of social behavior, moral standards are mastered, relations of equality and respect for each other are established here. Communication of a teenager with peers, comparing himself with others, interest in his own personality, his abilities and capabilities create favorable conditions for the development of self-awareness at this age. The main interests, social work, familiar lifestyle, traditions are associated with the collective of peers of a teenager. A teenager values the opinion of the team and individual peers, makes efforts to find and take a worthy place in the team.

Vygotsky (1960) among the main groups of vivid interests, which he defined as dominant, distinguishes the following key ones: the adolescent's interest in his own personality; setting the teenager on an extensive, large scale; teenager craving for resistance; the desire of the teenager for the unknown. Among the neoplasms of this age, the scientist noted the development of reflection and, on its basis, the development of self-consciousness.

In addition, Bozhkovich (1986) notes that towards the beginning of the transitional age, new, broader interests, personal hobbies and the desire to take a more independent, more "adult" position in life appear in the teenager's general mental development, a neoplasm is formed in adolescence, which she called "selfdetermination." From a subjective point of view, it is characterized by self-awareness as a member of society and is concretized in the new socially significant position of a teenager.

According to the fair judgment of Rogachev (1994), one of the tendencies of personality development in adolescence is the satisfaction of the need for search activity, which makes this age the most active, allows you to include a high school student in social activity, the features of which are determined by the intensive growth of self-awareness and the desire for self-realization. Adolescence is characterized by the fact that the need for organizational activity is increasing, adolescent children are ready to take on the role of a leader, to attract children to the organization of any activity.

Adolescence, as many researchers note, is characterized by an increased level of activity, independence, desire, first, with adults to participate in various activities, and then take their place, take responsibility, cares and obligations to them. Therefore, adults strive to see and feel the usefulness of the actions of schoolchildren, to engage in vivid socially significant activities, as was the case in the pioneer organization, and thereby form a field for self-realization with their correct life positions.

A characteristic feature of adolescence is the transformation of a child into an adult. A teenager has a desire to mean something. All this increases its activity, includes in public life. Children with pronounced collectivist motives, organizational abilities, as a rule, belong to this age group. Joining a teenager in a group involves finding him his place in the structure of the collective, where leaders are distinguished as a result of group differentiation.

The growth of social activity, the intensive development of the personality of a teenager, the formation of his worldview, self-awareness and the desire for self-realization allows us to determine adolescence as optimal for the development of leadership qualities.

Children's public associations can play an important compensatory role, provide the necessary level of selfesteem, maintain a favorable social status, serve as a condition for the protection of a teenager, and make up for the lack of events in life, emphasizes (Chugunova 2000).

Volokhov (2003) formulated the rules for including children in the activities of a children's public association: priority of the interests of the child's personality; the realization of the interests of each child; inadmissibility of including a child in activities contrary to his will; the priority of hobbies by example over preaching; respect for the personality of the child; inadmissibility of humiliation of his honor, dignity; equality of children and adults in resolving all issues related to the activities of the children's association; the unity of the requirements of everyone to everyone, each to everyone, including the requirements of adults for children and children for adults.

Considering the educational potential of children's public organizations, we came to the conclusion that children's organizations can be considered as educational spaces for the development of the personality of the younger generation. 


\section{Pedagogical possibilities of the educational space of children's public organizations}

At present, such phenomena as "the educational space of the everyday life of the school life of a teenager", the educational space of a kindergarten, urban and rural schools, and a small town have been studied. The factors of humanization of the educational space are investigated: national traditions, game; subculture of the school, institution of further education.

The educational space is understood by scientists as a humanitarian "environment in the environment" specially organized by teachers together with children, which creates not only additional, but also fundamentally new opportunities for developing a student's personality. This space is considered as a temporary combination of energy sources that can ensure the development of the personality in accordance with certain goals, and as a condition for the development of the child's personality.

Educational space is considered as a pedagogically organized environment. According to this position, the educational space is a pedagogically expediently organized environment that surrounds an individual child or many children (class, school, home, yard, community, village, small or big city, region). In this case, the main mechanism for creating an educational space is the interaction of educational, cultural, medical and other institutions, united by a common understanding of pedagogical tasks, common principles and approaches to education. Adherents of a different approach consider the educational space as part of the environment where a certain, pedagogically shaped lifestyle prevails.

According to Romaykin (2003) educational space is a dynamic network of interconnected pedagogical events, collected by the efforts of subjects of various levels (collective and individual) and capable of acting as an integrated condition for the personal development of a person, both adult and child. Based on the analysis of scientific works, several basic positions on the educational space can be formulated:

- $\quad$ space is a developed environment (natural, cultural, social, informational) adapted for solving educational problems;

- the concepts of "environment" and "space" are not identical: if the environment is a given, which is not the result of constructive human activity, then space is the result of the pedagogical development of this given;

- the educational space does not develop by itself or by order from above - it is born within the pedagogical reality due to specially organized activities;

- the educational space becomes a factor in the humanization of children's life, provided that it is a space of a children's community filled with real and meaningful questions for children, to which they need to find answers, if children perceive it as their own territory, for which they are responsible, are economically ready to protect from destruction;

- the creation of an educational space includes internal processes related to the selection of priorities for pedagogical activity, and external ones, including the development of the environment by the community of children and adults;

- an important characteristic of the educational space is its activity, understood as the ability to maintain in a group a level of emotional and intellectual tension sufficient for all participants in the interaction, stimulate the child's interrogative attitude to the world and creatively search for answers to questions that arise during his life.

The active educational space is remarkable in that it provides each child with the opportunity to meet new people, objects and phenomena, a high probability of an event that can arouse the personal interest of the participants in the interaction to what is happening. Romaykin (2003) believes that the educational space exists in an environmental context, and its existence inevitably entails managing the environment and the acquisition by the space of the characteristics of the educational environment.

Based on the above analysis of the category "educational space", under the educational space for the development of leadership qualities of adolescents, as part of our study, we mean a pedagogically mastered environment that creates not only additional, but also new opportunities in the development of leadership qualities of adolescents in a children's public association.

The special place of children's public associations in the educational space is determined by the implementation of the specific educational potential of the children's organization. The educational potential of a children's public association is a certain integrity of socio-psychological factors that determine the individual's needs for the life of the association, the position of the subject of knowledge, activity, communication, creativity, 
self-development. The core of the educational space is respect for the individual and her rights, the development of her desire for self-knowledge, self-improvement and self-realization.

Thus, children's organizations can be considered as an educational space for the development of not only the leadership qualities of adolescents, but also feelings of tolerance, self-confidence, self-expression, development of skills to engage in intercultural dialogue in the modern world.

\section{Formation of the experience of self-realization in the social environment}

Based on the foregoing, it follows that the children's public organization is the social institution that is able to provide the teenager with the opportunity to realize their own potential and gain experience in participating in various types of socially significant activities. According to the researchers of the children's movement, it is fundamentally important to realize the educational potential of the children's association is to create real opportunities for the individual to realize the goals, prospects of the organization, his stay and activity in it, the actualization and development of personal interests, needs, and opportunities; provision of personally significant multi-role activity, intense interpersonal and inter-age communication, a favorable position for everyone in the system of relations of a children's public organization.

Children's public organization provides adolescents with the opportunity of widespread and diversified inclusion in the system of public relations, organizes life activities that satisfy the teenager's developmental need. According to Lebedev (2003), openness and voluntariness of membership, emotional attractiveness of activity, great social rights (compared with the role of a student or child in the family), the possibility of choosing a specific type of activity, and joint forms of its organization determine the special socio-pedagogical opportunities of children's public organizations in the self-determination of adolescents. Everyone who enters a children's public organization is the subject of their own development in specific conditions related to national, cultural, ethnographic, social environment. Care and attention to the problems of the positive social formation of the emerging personality, the steady growth of the leader and creative potential of the child, the possibility of independent choice of one form or another of association make it possible to preserve the variety of organizational forms of children's initiative

In a children's social organization, a teenager, on an equal footing and with peers in life experience, can choose the forms and types of activities available to him, how to implement them, together with others, to experience satisfaction from the result of his efforts. The teenager in the process of activity cognizes himself, improves himself.

The possibilities of self-determination of adolescents in a children's social organization are expanding due to: dynamism and the inclusion of adolescents in a variety of activities where the adolescent gains experience of leadership behavior; the diversity realized by the adolescent in combining social roles (positions); expanding the circle of contacts, the presence of inter-age communication.

We emphasize that a children's public organization creates the conditions for satisfying the needs and interests of adolescents, for constructive, creative interaction. At the same time, the child retains the right to freely transfer from one child's public association to another. The strength of children's associations is that they educate a person who is able to make decisions, the experience of self-realization in the modern world through social interaction is formed.

\section{Conclusions}

Thus, a children's public organization based on the common interests of children and adults, voluntary inclusion in joint activities to solve specific problems, creates the conditions for: meeting the needs of a teenager in an equal position with an adult; actualization of opportunities unclaimed in other communities of which he was or is a member; elimination of the deficit of meaningful communication; development of social creativity, ability to interact with people, leadership qualities.

Children's public organization opens up opportunities for self-expression, self-realization of a person, promotes the formation of such aspects of the social experience of a growing personality, which in other educational organizations cannot be fully developed. A children's public organization enables students to reflectively assess their position in the organization's activities, their place in the children's team, especially their relationships with other members, and demonstrate leadership qualities. In adolescents, there is a need for the development of self-awareness, self-esteem, the need for other people to evaluate it. Entering the children's public organization, the children voluntarily accept the moral, spiritual, civic, patriotic guidelines of their life. They are expressed in laws, commandments, organization customs.

In a children's public organization, each child is given the opportunity to realize themselves as a real part of society with their rights, duties and their real, active manifestation; the presence in the children's public organization of subject-subject relations; the presence of socially oriented activities that are diverse in content that contribute to the cognition, development, self-realization of a person, and the acquisition of experience in 
leadership behavior; the variety realized by the adolescent in the organization of social roles (positions) are prerequisites for the formation of leadership qualities of adolescents. Consequently, children's social organization can be considered as the educational space of the most positive, prosperous, effective development of leadership qualities of adolescents - its participants.

\section{References}

Bondar MA (2013) Osobennosti fenomena “detskaya obschestvennaya organizaciya”. Molodoy ucheny 3: 463468 .

Bozhkovich LI, Lichnost I yeyo formirovaniye v detskom vozraste, $1^{\text {st }}$ edn. (Prosvescheniye: Moscow, 1986), 464 p.

Chugunova OD (2000) Detskoye obschestvennoye obyedineniye kak sposob pedagogicheskogo vliyaniya na socialnuyu aktivnost podrostkov, Dissertaciya kandidata pedagogicheskikh nauk, Kostroma: KSU, pp. 58-61.

Dmitrenko (1996) Tri vzglyada na odin potencial. TIM: Teoriya, istoriya, metodika detskogo dvizheniya. Infromacionnaya bulleten 1: 123.

Kovrov VA, Lebedev DN, Kulpedinova ME (1996) “Ja” stanovitsya bogache. Teoriya, istoriya, metodika detskogo dvizheniya (TIM). Informacionnaya bulleten 1:53.

Lebedev DN (2003) Detskoye obschestvennoye dvizheniye: ispytaniye vremenem. Vospitaniye shkolnikov 1:57.

Maltseva EA, Detskaya obschesvennaya organizaciya. Detskoye dvizheniye. Slovar-spravochnik, $2^{\text {nd }}$ edn (Prosvescheniye: Moscow, 2005), 54 p.

Maltseva EA, Kostina NM, Pedagogika detskogo dvizheniya, $1^{\text {st }}$ edn. (Udmurtskiy Universitet: Izhevsk, 2000) $516 \mathrm{p}$.

Rogachev VV (1994) Pedagogicheskiye usloviya vklucheniya starsheklassnikov v socialnuyu deyatelnost, Dissertaciya kandidata pedagogicheskikh nauk, Yaroslavl: YSPU, 39 p.

Romaykin VY (2003) Sootnosheniye ponyatiy "vospitatelnaya sreda" I "vospitatelnoye prostranstvo". Pedagogicheskiy vestnik 3: 36.

Volokhov AV (2003) Variantno-programny podhod v deyatelnosti detskikh obschestvennykh obyedineniy. Vospitaniye shkolnikov 4: 56-64.

Vygotsky LS (1960) Razvitiye vysshikh psikhicheskikh funkciy, $1^{\text {st }}$ edn. (APN: Moscow, 1960) 500 p.

Yablokova EA, Psikhologiya kollektiva I lichnost, $1^{\text {st }}$ edn. (MSU: Moscow, 1997) 88 p. 